\title{
Cytoplasmic Alkalinization during Germ Tube Formation in Candida albicans
}

\author{
By ELAINE STEWART, ${ }^{1}$ NEIL A. R. GOW ${ }^{1 *}$ aND DAVID V. BOWEN ${ }^{2}$ \\ ${ }^{1}$ Department of Genetics and Microbiology, Marischal College, University of Aberdeen, \\ Aberdeen AB9 IAS, UK \\ ${ }^{2}$ Analytical Chemistry Department, Pfizer Central Research, Sandwich, Kent CT13 9NJ, UK
}

(Received 18 December 1987)

\begin{abstract}
Weak acids were used to measure the internal $\mathrm{pH}$ of yeast cells of Candida albicans that had been induced to form buds or germ tubes. Under conditions that supported germ tube formation the internal $\mathrm{pH}$ rose from around 6.8 to over $8.0 \mathrm{after} 30 \mathrm{~min}$ in two different induction media. Internal $\mathrm{pH}$ measured by ${ }^{31} \mathrm{P}$ NMR confirmed this pattern and also showed that the internal $\mathrm{pH}$ fell to around 7.0 prior to the outgrowth of germ tubes. Conditions which led to budding induced less cytoplasmic alkalinization. This alkalinization was brought about when cells were inoculated into media of neutral $\mathrm{pH}$ and at an increased temperature. Increasing the temperature of the medium augmented the alkalinization of the cytoplasm induced by raising the external $\mathrm{pH}$. Strains of $C$. albicans defective in the ability to produce germ tubes did not show this dramatic cytoplasmic alkalinization under conditions which normally supported filamentous growth. The raising of internal $\mathrm{pH}$ may be due to the activation of the plasma membrane proton-pumping ATPase since diethylstilboestrol inhibited the cytoplasmic alkalinization and germ tube formation without causing irreversible loss of cell viability. The results show that the induction of the dimorphic transition in this organism is accompanied by a steep rise in internal $\mathrm{pH}$. It is not known whether these changes are the cause or consequence of morphogenesis.
\end{abstract}

\section{INTRODUCTION}

The role of the environment in controlling the morphology of Candida albicans has been studied extensively, yet remains elusive. A wide range of nutritional factors have been shown to be important in selectively encouraging growth by hyphal extension or by budding (Odds, 1979). However, no single environmental factor is responsible for inducing the dimorphic shift. Filamentous growth is favoured by conditions of neutral external $\mathrm{pH}$ and a temperature of around $37^{\circ} \mathrm{C}$ (Odds, 1985). The inherent sensitivity of $C$. albicans to alterations in external $\mathrm{pH}$ is exploited in experimental protocols in which external $\mathrm{pH}$ alone is used to control structural dimorphism (Lee et al., 1975; Buffo et al., 1984). In these protocols a batch culture of yeast cells is grown at $25^{\circ} \mathrm{C}$ in a synthetic medium of pH 4.5 until the cells reach stationary phase. Inoculation of these cells into fresh medium induces growth by germ tube formation when the medium is at $\mathrm{pH} 6.5$ and $37^{\circ} \mathrm{C}$ and by budding in the same medium at $\mathrm{pH} 4.5$ and a temperature of 25 or $37^{\circ} \mathrm{C}$ (Buffo et al., 1984). This method is therefore ideal for investigations of environmentally induced dimorphism. There has been much less work investigating the physiological consequences of those conditions which select for one growth form over the other although there is detailed information regarding the changes occurring in cell shape, ultrastructure and wall biosynthesis and metabolism as a consequence of dimorphic transitions (Soll, 1985, 1986; Gow \& Gooday, 1984; Cassone et al., 1985; Shepherd et al., 1985). The rationale for this study was to investigate the effects of external $\mathrm{pH}$, temperature and medium composition on internal $\mathrm{pH}$.

Abbreviation: DMO, 5,5-dimethyloxazolidine-2,4-dione. 
Changes in internal $\mathrm{pH}$ have been implicated in the control of cellular differentiation, metabolism and cell cycle events in a wide range of organisms including the activation of sea urchin and Xenopus eggs (Johnson et al., 1976; Winkler \& Grainger, 1978; Charbonneau \& Webb, 1987), stalk cell differentiation in Dictyostelium discoideum (Gross et al., 1983), germination of yeast ascospores (Barton et al., 1980) and the control of starvation, refeeding and catabolite derepression in Saccharomyces cerevisiae (den Hollander et al., 1981). For a review see Busa \& Nuccitelli (1984). Internal pH transitions responsible for these events almost invariably involve a rise in internal $\mathrm{pH}$ which varies in magnitude between 0.1 and $1.6 \mathrm{pH}$ units (Busa \& Nuccitelli, 1984).

In this paper we report that there is dramatic alkalinization of the cell cytoplasm of C.albicans prior to the emergence of the germ tube and that this alkalinization does not occur in those strains which do not form germ tubes. We also present preliminary evidence that alkalinization may be due to the activation of proton-pumping by the cytoplasmic membrane ATPase under conditions that promote filamentous growth.

\section{METHODS}

Organisms and culture conditions. Candida albicans (Robin) Berkhout strain 3153 was obtained from the London Mycological Reference Laboratory. The non-inducible strain $\mathrm{CA}_{2}$ and germ-tube-minus mutant 100192' were gifts from Antonio Cassone (Istituto di Microbiologia, University of Rome, Italy) and César Nombela (Departmento de Microbiología, Universidad Complutense, Madrid, Spain), respectively. Cells were grown in liquid media in $250 \mathrm{ml}$ glass Erlenmeyer shake-flasks. Germ tube or budding growth was induced from stationary phase yeast cultures using an amino acids/salts medium or medium containing $N$-acetylglucosamine according to the methods of Buffo et al. (1984) and Gopal et al. (1982) respectively. Cells were inoculated into media inducing germ tubes or buds at a concentration of $5 \times 10^{7}$ yeast cells $\mathrm{ml}^{-1}$ and flasks were stirred to ensure mixing of added radiochemicals and aeration of the culture. Control experiments showed that $5 \times 10^{7}$ cells $\mathrm{ml}^{-1}$ was the maximum density that could be achieved without reducing the proportion of cells that formed germ tubes. Induction using amino acids/salts medium was under conditions of zinc sufficiency (Anderson \& Soll, 1984). Saccharomyces cerevisiae 106 was from the University of Aberdeen culture collection.

Measurement of internal pH using weak acids. The internal $\mathrm{pH}$ of cells was measured by determining the distribution of the radiolabelled weak acids $\left[7-{ }^{14} \mathrm{C}\right]$ benzoate and 5,5-dimethyl[ $\left.2-{ }^{14} \mathrm{C}\right]$ oxazolidine-2,4-dione (DMO) according to the method of Booth et al. (1979). These weak acids were used at final concentrations of $0.6 \mu \mathrm{M}\left[19.3 \mathrm{Ci} \mathrm{mol}^{-1}\left(714 \mathrm{GBq} \mathrm{mol}^{-1}\right)\right]$ and $0.5 \mu \mathrm{M}\left[16.2 \mathrm{Ci} \mathrm{mol}^{-1}\left(600 \mathrm{GBq} \mathrm{mol}^{-1}\right)\right]$, respectively, and were added with ${ }^{3} \mathrm{H}_{2} \mathrm{O}$ [1 $\mu \mathrm{Ci} \mathrm{ml}^{-1}\left(37 \mathrm{kBq} \mathrm{ml}^{-1}\right)$ final concentration] as a total water marker. Control experiments showed that these compounds equilibrated within $2 \mathrm{~min}$. Triplicate $1 \mathrm{ml}$ samples were taken at intervals and centrifuged in Eppendorf tubes for $30 \mathrm{~s}$. A $100 \mu \mathrm{l}$ volume of the supernatant was removed from each tube and transferred to Eppendorf tubes containing pellets of equal numbers of cells which had not been exposed to radiochemicals. This enabled the degree of quenching caused by the cells to be accounted for when comparing radioactivity in pellets and supernatants. The ${ }^{3} \mathrm{H}_{2} \mathrm{O}$ count enabled the total volume of pellets to be determined and the amount of extracellular (trapped) ${ }^{1+} \mathrm{C}$ in pellets to be calculated. Pellets were resuspended in $100 \mu 1$ fresh medium and $80 \mu \mathrm{l}$ of this was added to $2 \mathrm{ml}$ scintillation fluid (Optiphase X, LKB). The radioactivity in samples of supernatant and pellet was counted using a Packard Tricarb $300 \mathrm{C}$ scintillation counter with the ${ }^{3} \mathrm{H}$ and ${ }^{14} \mathrm{C}$ window settings at $0-12 \mathrm{keV}$ and $12-156 \mathrm{keV}$ respectively. The ${ }^{1+} \mathrm{C}$ spillover into the ${ }^{3} \mathrm{H}$ channel was estimated using identical samples containing ${ }^{1+} \mathrm{C}$ only. From a knowledge of the external $\mathrm{pH}$ and the $\mathrm{p} K$ of the weak acid the internal pH was calculated (Booth et al., 1979).

Measurement of internal pH using ${ }^{31} P$ NMR. Measurements of internal $\mathrm{pH}$ were made in cells in stationary phase and at various times after the induction of germ tube formation in amino acids/salts medium at $\mathrm{pH} 6.5$ and $37^{\circ} \mathrm{C}$. In order to obtain a working signal the cells had to be prepared at a concentration of $2.5 \times 10^{9}$ cells ml $^{-1}-$ a density at which the cells failed to form germ tubes. Thus each measurement was made separately on a sample of cells prepared for a particular time point. The cells were induced in media at a concentration of $5 \times 10^{7} \mathrm{cells}^{-1}$ and then concentrated to the working concentration. $\mathrm{D}_{2} \mathrm{O}(2 \%, \mathrm{v} / \mathrm{v})$ was added as an internal standard to $2.5 \mathrm{ml}$ of cell supension. Spectra were also referenced to $85 \%(\mathrm{w} / \mathrm{v}) \mathrm{H}_{3} \mathrm{PO}_{4}$ in a separate $\mathrm{NMR}$ tube. Spectra were recorded on Bruker WM250 or General Electric GN500 NMR spectrometers tuned at $101.256 \mathrm{MHz}$ and $202.443 \mathrm{MHz}$, respectively. The pulse angle was at $57^{\circ}, 75^{\circ}$ or $90^{\circ}$ (optimum $90^{\circ}$ ) with $20-26 \mu$ s pulses and a relaxation delay of $100 \mathrm{~ms}$. Typically 2000 scans were made over a period of $8.3 \mathrm{~min}$ (acquisition time $128 \mathrm{~ms}$ ). The chemical shifts were calibrated using solutions of $10 \mathrm{~mm}-\mathrm{KH}_{2} \mathrm{PO}_{4}$ at a range of $\mathrm{pH}$ values. Since some spectra were recorded at $37^{\circ} \mathrm{C}$ and others at $25^{\circ} \mathrm{C}$ calibration measurements were corrected for temperature where necessary. The amino acids/salts medium contained appreciable amounts of phosphate and gave a strong signal but the internal $\mathrm{pH}$ was 
found to be in all cases more alkaline than the external $\mathrm{pH}$ and so the internal phosphate signal was readily identifiable. Bubbling of air into sample tubes had no effect on the values of the internal $\mathrm{pH}$ that were obtained. Spectra had a higher background noise when samples were aerated and so most spectra were made without aerating the cultures. The concentrated cell suspensions noticeably acidified the sample growth medium. The external $\mathrm{pH}$ fell by $1 \mathrm{pH}$ unit (from 6.5 to 5.5 ) within the time it took to make the 2000 scans.

Cell volume determinations. Attempts to measure the extracellular water space using $\left[{ }^{3} \mathrm{H}\right]$ inulin, carboxymethylinulin and D-lactose were unsuccessful. Inulin and carboxymethyl-inulin bound to the cell surface while lactose permeated the cells (data not shown). Instead, yeast cells were stained with $5 \mu \mathrm{g} \mathrm{Calcofluor}$ white $\mathrm{ml}^{-1}$ (American Cyanamid) and the volume was calculated from the dimensions of the ellipsoid axes as measured at a magnification of $1000 \times$ in an Olympus fluorescence microscope. Calcofluor stained cells had a clearly defined boundary which facilitated these measurements. The mean cell volume of stationary phase cells of strain 3153 was $45 \cdot 1 \pm 1 \cdot 1 \mu \mathrm{m}^{3}(n=100)$. This figure is in close agreement with figures published elsewhere for the same strains and cultural conditions (Herman \& Soll, 1984). The mean cell volume of cells after $30 \mathrm{~min}$ in amino acids/salts medium, pH $6.5,37^{\circ} \mathrm{C}$ was $44.5 \mu \mathrm{m}^{3}$. Mean volumes of stationary phase cells of C. albicans strains $100192^{\prime}$ and $\mathrm{CA}_{2}$ were 43.4 and $46.1 \mu \mathrm{m}^{3}$ respectively.

Analysis of germ tube and budding growth. Small volumes of induced cultures were removed, fixed in buffered formalin solution and the percentage of cells showing any visible germ tube was recorded for 100 specimens. Cell densities were determined by counting in an Improved Neubauer haemocytometer.

Sources of chemicals. Radiolabelled DMO and benzoate were from Amersham and New England Nuclear, respectively. Diethylstilboestrol, procaine, nicotine and benzylamine were from Sigma.

\section{RESULTS}

\section{Use of weak acids to measure internal pH in C. albicans}

Internal $\mathrm{pH}$ in cells forming buds and germ tubes was followed for the first $30 \mathrm{~min}$ after the induction of growth. The changes in internal $\mathrm{pH}$ therefore reflected events preceding the emergence of buds or germ tubes which occurred after $30 \mathrm{~min}$ in the amino acids/salts medium. Germ tubes started to form after $60 \mathrm{~min}$ but maximum germ tube formation occurred only after 360 min. Unlike Herman \& Soll (1984) we found that the mean volume of the yeast cells did not increase significantly during the first $30 \mathrm{~min}$ in fresh growth medium. Measurement of internal pH after evagination of buds or germ tubes was complicated by the difficulty in making accurate cell volume determinations for mixed populations of evaginating and non-evaginating cells and by the knowledge that the acidic vacuolar space increases dramatically at the onset of filamentous growth (Gow \& Gooday, 1982; Gow et al., 1986). These difficulties were overcome by monitoring the initial changes which occurred prior to the formation of buds or germ tubes during which time the cell volume and vacuolar volume were constant. Moreover, since we were interested in those events which might control dimorphism these would necessarily precede morphogenesis. Experiments using weak acids were therefore restricted to those events which preceded the morphological changes associated with dimorphism.

Control experiments showed that benzoate and DMO equilibrated within 2 min and gave closely comparable values for the internal $\mathrm{pH}$, although under conditions where internal $\mathrm{pH}$ was most alkaline, benzoate gave values up to 0.4 units higher than those obtained with DMO. This may be due to the lower $\mathrm{p} K$ of benzoate ( 4.2 compared to 6.32 for DMO) and the accumulation of appreciable amounts of this acid in the acidic vacuoles. C. albicans was not able to use benzoate or DMO as sole carbon source for growth on agarose plates containing nitrate, ammonium and inorganic nutrients. Cells were loaded with DMO or benzoate and then broken open in a Braun MSK glass-bead homogenizer and the homogenate run on TLC plates using a solvent of chloroform/cyclohexane/acetic acid $(80: 20: 10$, by vol.). No detectable breakdown of the intracellular radiolabelled acid could be observed on autoradiograms of the plates indicating that the cells did not metabolize the acids. Cells loaded with benzoate or DMO showed free efflux of the radiolabel when placed in non-labelled (weak-acid-free) medium indicating that the acids were not bound inside the cells. Also, the addition of $1 \%(\mathrm{v} / \mathrm{v})$ toluene or $n$-butanol made the membrane permeable and prevented the acids from accumulating above extracellular concentrations. In some experiments internal $\mathrm{pH}$ was checked by concentrating the cells, breaking them open in non-buffered medium in a Braun homogenizer and measuring the $\mathrm{pH}$ of the homogenate. This crude technique produced values that were within $0.3 \mathrm{pH}$ units of those 


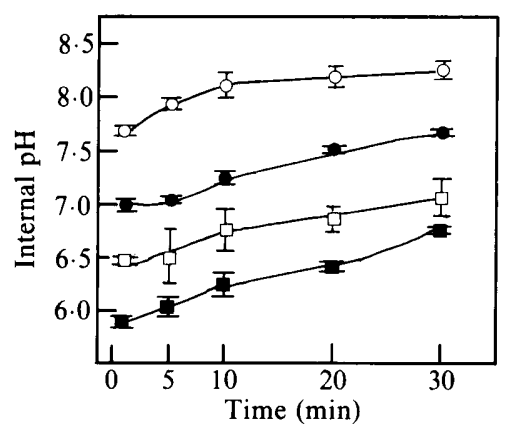

Fig. 1

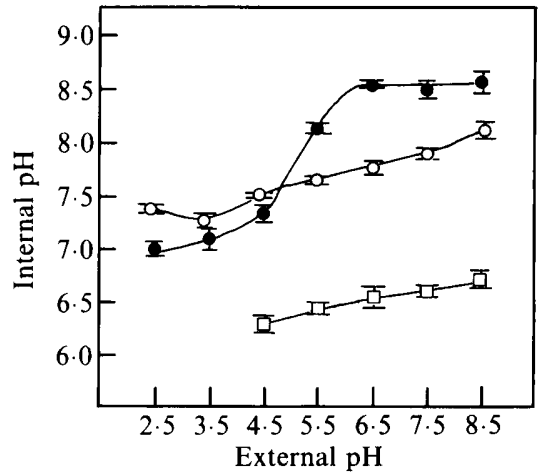

Fig. 2

Fig. 1. Changes in internal $\mathrm{pH}$ after stationary phase cells of $C$. albicans were inoculated into growth medium at $37^{\circ} \mathrm{C}$, pH $6.5(\mathrm{O}), 37^{\circ} \mathrm{C}$, pH $4.5(\bigcirc), 25^{\circ} \mathrm{C}$, pH $6.5(\square)$ or $25^{\circ} \mathrm{C}$, pH $4.5(\square)$. Germ tube formation occurred only at $37^{\circ} \mathrm{C}, \mathrm{pH} 6.5$. Error bars are SD values based on nine determinations from three separate experiments. Internal $\mathrm{pH}$ was determined using DMO.

Fig. 2. Effect of external $\mathrm{pH}$ on internal $\mathrm{pH}$ in yeast cells of $C$. albicans $(\mathrm{O}, \boldsymbol{O})$ or $S$. cerevisiae $(\square)$. Values for $C$. albicans were for stationary phase cells at $37^{\circ} \mathrm{C}(\mathrm{O})$ or for cells inoculated into fresh growth medium and incubated for $30 \mathrm{~min}$ at $37^{\circ} \mathrm{C}(\mathrm{O})$. The values for $S$. cerevisiae were for cells $30 \mathrm{~min}$ after inoculation into the same medium but at $30^{\circ} \mathrm{C}$. Error bars are SD values based on nine determinations from three separate experiments using benzoate to determine internal $\mathrm{pH}$.

measured using DMO. The use of newborn calf serum medium was found unsuitable for use in experiments for determinations of internal $\mathrm{pH}$. The radiolabels were bound extracellularly in appreciable quantities in the presence of $20 \%(\mathrm{v} / \mathrm{v})$ serum. Data obtained with ${ }^{31} \mathrm{P}$ NMR were comparable with those obtained using weak acids (see below).

\section{Effect of external $\mathrm{pH}$ and temperature on internal $\mathrm{pH}$}

Stationary phase yeast cells of C. albicans were inoculated into fresh medium at $\mathrm{pH} 4.5$ at 25 or $37^{\circ} \mathrm{C}$ or at pH 6.5 at $37^{\circ} \mathrm{C}$ according to the method of Buffo et al. (1984). Germ tubes were formed with the latter set of conditions while growth was by bud formation when the medium was at the lower $\mathrm{pH}$ and/or temperature. The internal $\mathrm{pH}$ of the stationary phase cells at $25^{\circ} \mathrm{C}$ was $6.8 \pm 0.15$ as measured using benzoate or DMO. The internal $\mathrm{pH}$ was also estimated at 6.63 by recording the $\mathrm{pH}$ of homogenates of these cells. There was a rapid rise in internal $\mathrm{pH}$ within the time taken to make the first measurement after inoculation into fresh medium followed by a gradual increase in internal $\mathrm{pH}$ over the next $30 \mathrm{~min}$ (Fig. 1). The increase was largest under those conditions leading to eventual germ tube formation where internal $\mathrm{pH}$ rose from 6.8 to 8.2 in $30 \mathrm{~min}$. The $\mathrm{pH}$ of a homogenate of cells at this stage of growth was 7.92. This cytoplasmic alkalinization was less pronounced when the growth medium was at the lower temperature or $\mathrm{pH}$ (Fig. 1). Replicate experiments using benzoate to measure internal $\mathrm{pH}$ gave values that were higher. The difference was greatest when cytoplasmic pH was most alkaline (see Fig. 2). Cells of $C$. albicans and $S$. cerevisiae were cultured in fresh medium of identical composition but varying $\mathrm{pH}$; internal pH was then measured $30 \mathrm{~min}$ after inoculation (Fig. 2). C. albicans had a more alkaline and less constant cytoplasmic $\mathrm{pH}$ than $S$. cerevisiae. The internal $\mathrm{pH}$ of non-growing stationary phase yeast cells of C. albicans varied less over the same range of external pH (Fig. 2). The inoculation of stationary phase cells of $S$. cerevisiae into fresh growth medium at $\mathrm{pH}$ of either 4.5 or 6.5 led to only a slight rise in internal $\mathrm{pH}$ in comparison with that observed with $C$. albicans (data not shown). The dramatic increase in internal $\mathrm{pH}$ seen with $C$. albicans under similar conditions is therefore a feature of the physiology of this organism rather than a general effect of the culture conditions used.

Changes in internal $\mathrm{pH}$ occurred in response to alterations in external $\mathrm{pH}$ and in temperature. An increase in temperature alone was found to increase internal pH (Fig. 3). Decreasing the 


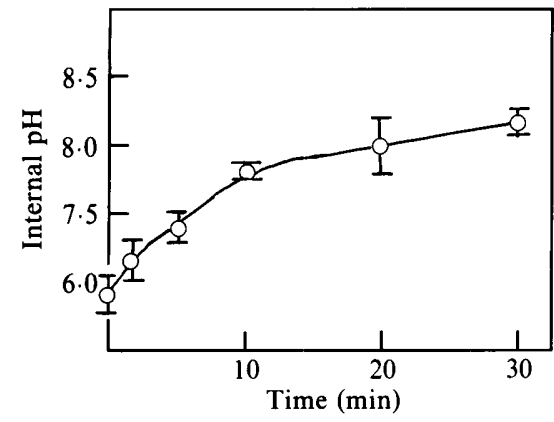

Fig. 3

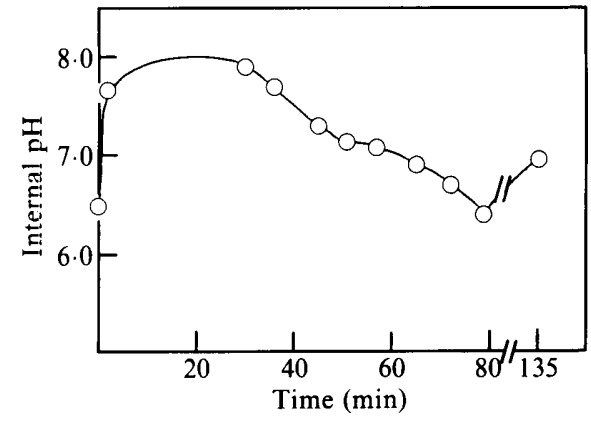

Fig. 4

Fig. 3. Effect of an increase in temperature on internal $\mathrm{pH}$. Cells were preincubated for $63 \mathrm{~min}$ at $25^{\circ} \mathrm{C}$ in nutrient depleted (stationary phase) medium at pH 4.5 before the temperature was increased to $37^{\circ} \mathrm{C}$ at time $=0$. Error bars are SD values of triplicate measurements using benzoate to determine internal $\mathrm{pH}$.

Fig. 4. Changes in internal $\mathrm{pH}$ during the induction of germ tubes in media at $37^{\circ} \mathrm{C}$ and $\mathrm{pH} 6 \cdot 5$. Internal $\mathrm{pH}$ measurements were made by ${ }^{31} \mathrm{P}$ NMR; each point was determined from a single experiment as described in Methods.

temperature to $4{ }^{\circ} \mathrm{C}$ decreased the value obtained for internal $\mathrm{pH}$ by over $1 \mathrm{pH}$ unit. Changes in temperature therefore potentiate internal $\mathrm{pH}$ changes brought about by altering external $\mathrm{pH}$. Alterations in temperature and $\mathrm{pH}$ of the medium both contribute to an alkalinization of the cell cytoplasm. Increasing the cell density of cultures from $5 \times 10^{7}$ to $2.5 \times 10^{9} \mathrm{ml}^{-1}$ had the effect of reducing equivalent internal $\mathrm{pH}$ values by around half a $\mathrm{pH}$ unit. This may be due to the concentrated cells actively acidifying the medium.

\section{Internal $p H$ changes measured by ${ }^{31} P N M R$}

Samples were prepared as described in Methods and the internal $\mathrm{pH}$ determined from the chemical shift measured for the internal phosphate peak (Fig. 4). The spectra were recorded at the same temperature that was used in the experiments. The internal $\mathrm{pH}$ of stationary phase cells was determined as $6.5-$ lower than that determined using weak acids (6.8). After induction of germ tube formation the internal $\mathrm{pH}$ rose to 7.8 or above before falling to around 7.0 at $135 \mathrm{~min}$. Since around $10 \%$ of cells had formed germ tubes by this time it was clear that the internal $\mathrm{pH}$ of growing cells was around neutrality.

\section{Internal pH changes in medium containing $\mathrm{N}$-acetylglucosamine}

In order to establish whether the cytoplasmic alkalinization accompanying germ tube formation in amino acids/salts medium (Buffo et al., 1984) was a general feature of the dimorphic transition, we followed internal $\mathrm{pH}$ in cells induced in medium containing $\mathrm{N}$ acetylglucosamine (Gopal et al., 1982). When the $\mathrm{pH}$ and temperature of this medium was 4.5 and $25^{\circ} \mathrm{C}$, respectively, cells failed to form germ tubes and internal $\mathrm{pH}$ rose to 7.7 after $30 \mathrm{~min}$ (data not shown). At $37^{\circ} \mathrm{C}$ and an external pH of 6.5 cells formed germ tubes and again the internal $\mathrm{pH}$ rose to above 8.0 . The difference in internal $\mathrm{pH}$ of germ-tube-forming and budforming cells was not therefore as great as in amino acids/salts medium.

\section{Internal pH in germ-tube-less strains of C. albicans}

Two strains defective in their ability to produce germ tubes under conditions that normally support filamentous growth were used in studies of internal $\mathrm{pH}$. Strain $\mathrm{CA}_{2}$ is a 'low responder' (Mattia et al., 1982) strain, and produced only $4 \%$ germ tubes after $6 \mathrm{~h}$ in amino acids/salts medium. Strain $100192^{\prime}$, a germ-tube-less mutant, produced no germ tubes under the same conditions. The internal $\mathrm{pH}$ of these germ-tube-less strains did not rise as much as in strain 3153 during the first $30 \mathrm{~min}$ after inoculation into media that promotes hyphal growth (data not 


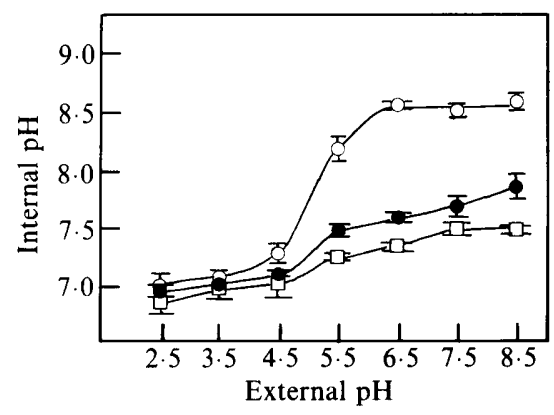

Fig. 5. Effect of external pH on internal pH of $C$. albicans strains $3153(\mathrm{O}), \mathrm{CA}_{2}\left(\mathrm{O}^{\prime}\right.$ ) and $100192^{\prime}(\square)$ 30 min after inoculation of cells from stationary phase cultures into growth medium at $37^{\circ} \mathrm{C}$ and pH 6.5. Error bars are SD values of nine measurements from three experiments using benzoate to determine internal $\mathrm{pH}$.

shown). In $\mathrm{CA}_{2}$ and $100192^{\prime}$ the internal $\mathrm{pH}$ rose to 7.85 and $7 \cdot 70$, respectively, after $30 \mathrm{~min}$ in fresh medium at $37^{\circ} \mathrm{C}$ and $\mathrm{pH} 6.5$. The internal $\mathrm{pH}$ of each strain reached $7 \cdot 10$ and 6.95 after the same period in fresh medium at $25^{\circ} \mathrm{C}$ and $\mathrm{pH} 4.5$. These strains were therefore better able to regulate their internal $\mathrm{pH}$ compared to the wild-type strain 3153 (Fig. 5).

\section{Effect of diethylstilboestrol on internal alkalinization}

We reasoned that one way in which a rapid alkalinization of the cytoplasm could be achieved would be through the activation of the cytoplasmic membrane ATPase. This proton pump expels protons electrogenically and its activity can be inhibited relatively specifically by diethylstilboestrol (Goffeau \& Slayman, 1981; Hubbard et al., 1985). We therefore studied the effect of this drug on internal $\mathrm{pH}$ and on germ tube formation. Diethylstilboestrol (dissolved in ethanol) was used at a final concentration of $0.1 \mathrm{~mm}$ (final ethanol concentration $1 \%$ ). When added at the beginning of a germ tube induction experiment diethylstilboestrol prevented internal $\mathrm{pH}$ from rising above 7.5 and when added $10 \mathrm{~min}$ after induction it prevented any subsequent alkalinization and led to a slight decrease in internal $\mathrm{pH}$. In neither case did germ tube formation occur. This was not due to the killing of the cells since the treated cells could be washed free of diethylstilboestrol after $30 \mathrm{~min}$ in its presence and be shown to have no decreased viability as assessed by a viable numbers count. Washed cells formed germ tubes readily $(92 \%$ germ tube formation) if they were resuspended in fresh medium for $6 \mathrm{~h}$. Controls using $1 \%$ ethanol alone had no effect on internal $\mathrm{pH}$ or germ tube formation.

\section{Induction of germ tube formation using weak bases}

We wondered whether treatments that increased internal $\mathrm{pH}$ would lead to the induction of germ tube formation. Weak bases such as procaine, nicotine and benzylamine can be used to raise the internal $\mathrm{pH}$ of fungi (Sanders \& Slayman, 1982). In order to do this the $\mathrm{p} K_{\mathrm{a}}$ of the base ought to be higher than the internal $\mathrm{pH}$ and the external $\mathrm{pH}$ ought to be sufficiently high to allow significant quantities of the free base to be generated externally. The $\mathrm{p} K_{\mathrm{a}}$ values of procaine, nicotine and benzylamine are $9 \cdot 0,8 \cdot 2$ and $9 \cdot 33$, respectively, and so experiments cannot readily be done under conditions that are physiological yet allow appreciable quantities of base to enter the cells. We used these weak bases at a rather low external $\mathrm{pH}(4 \cdot 5)$ yet were able to show that they could partially induce germ tube formation under conditions that would normally support growth by budding. In fresh growth medium containing $1 \mathrm{~mm}$-procaine at $25^{\circ} \mathrm{C}$ and titrated to $\mathrm{pH} 4.5$, the internal pH of cells rose to $7 \cdot 81$ and $20 \%$ of the cells formed germ tubes by $6 \mathrm{~h}$. Nicotine at the same concentration increased internal pH to 8.07 and increased the proportion of cells with germ tubes to $31 \%$. Benzylamine ( $1 \mathrm{~mm}$ ) failed to increase internal $\mathrm{pH}$ above $7 \cdot 0$ and did not induce germ tube formation. Concentrations of procaine and nicotine at or above $50 \mathrm{~mm}$ caused clumping and some lysis of the cells. Increasing the concentration of the weak 
bases did not increase further the degree of germ tube formation. Similar results were obtained when the experiments were repeated at $37^{\circ} \mathrm{C}$ and an external $\mathrm{pH}$ of $4 \cdot 5$. Benzylamine appeared to be able to permeate the cells and bring about cytoplasmic alkalinization and germ tube formation at the higher temperature. Because of the extremely low external $\mathrm{pH}$ used in these experiments the internal concentration of these bases must be assumed to be vanishingly small $(<0 \cdot 1 \mu \mathrm{M})$ and therefore incapable of increasing internal $\mathrm{pH}$ directly. We must conclude that the weak bases acted by activating processes which led to cytoplasmic alkalinization and not by increasing cytoplasmic $\mathrm{pH}$ directly.

\section{DISCUSSION}

We have shown that conditions that lead to filamentous growth in $C$. albicans also lead to alkalinization of the cell cytoplasm to $\mathrm{pH} 8.0$ or above. This $\mathrm{pH}$ change was larger than that observed when cells resumed growth by budding and was not seen under identical cultural conditions in strains unable to undergo dimorphism. The finding that temperature and $\mathrm{pH}$ both influence internal $\mathrm{pH}$ is of interest since these have been recognized as key environmental parameters in the control of dimorphism (Odds, 1979, 1985; Buffo et al., 1984). When the external $\mathrm{pH}$ was at or below 4.5 cells did not undergo the increasing cytoplasmic alkalinization that was evident when the external $\mathrm{pH}$ was raised above this value. This is of interest since Buffo et al. (1984) reported a similar transition for the effect of external $\mathrm{pH}$ on the induction of either budding or germ tube development. An inhibitor of the plasma membrane ATPase prevented cytoplasmic alkalinization and inhibited dimorphism. The increase in internal $\mathrm{pH}$ may therefore be induced by the activation of proton-pumping by the ATPase. Culture conditions used to induce germ tube formation in $C$. albicans had little effect on the internal $\mathrm{pH}$ of $S$. cerevisiae and in general it appeared that $C$. albicans did not regulate its internal $\mathrm{pH}$ as tightly as $S$. cerevisiae.

The values reported here for internal $\mathrm{pH}$ of $S$. cerevisiae are in close agreement with those published elsewhere (Krebs et al., 1983; Borst-Pauwels, 1981). We show that the internal pH of $S$. cerevisiae varies by less than $0.4 \mathrm{pH}$ units over a range of external $\mathrm{pH}$ values that generate a difference of more than $1.2 \mathrm{pH}$ units in $C$. albicans. The internal $\mathrm{pH}$ of exponential phase yeast cells and stationary phase cells of $C$. albicans was between 6.8 and 7.0 when the external $\mathrm{pH}$ was between 4.5 and 2.5 . Internal $\mathrm{pH}$ of stationary phase cells rose to 7.8 and 8.1 at 25 and $37^{\circ} \mathrm{C}$ respectively when the medium $\mathrm{pH}$ was titrated to 8.5 . These data are in general agreement with those of Prasad \& Hofer $(1987)$ who used $\left[{ }^{14} \mathrm{C}\right]$ propionate to measure internal $\mathrm{pH}$ of late exponential phase cells at between 7.3 and 8.1 when external $\mathrm{pH}$ was varied from 3.5 to 8.5 . Cassone et al. (1983) used ${ }^{31} \mathrm{P}$ NMR to measure internal $\mathrm{pH}$ in yeast cells, germ tubes and hyphae of $C$. albicans. Germ tube $\mathrm{pH}$ was estimated at 6.4 in packed cell suspensions at $4{ }^{\circ} \mathrm{C}$, 90 min after induction. We have shown that cooling and concentrating cells both led to a reduction in the value of the internal $\mathrm{pH}$ that was obtained. We repeated experiments measuring internal $\mathrm{pH}$ using benzoate or DMO at $4{ }^{\circ} \mathrm{C}$ and obtained a value of 6.7 for germ tubes after 30 min growth. As reported previously (Borst-Pauwels, 1981) values for internal pH obtained by NMR tended to be lower than those obtained by other methods. We also used ${ }^{31} \mathrm{P}$ NMR at physiological temperatures to provide corroborative evidence for the results obtained using weak acids.

A wide range of biochemical factors have been implicated in a variety of dimorphic fungi as being central to the control of yeast/mould dimorphism (San-Blas \& San-Blas, 1984; Odds, 1985). Of these, two molecules which have received much attention are the calcium binding protein calmodulin (Hubbard et al., 1982; Muthukumar \& Nickerson, 1984; Muthukumar et al., 1987) and cAMP (Maresca et al., 1977; Niimi et al., 1980; Chattaway et al., 1981). The activity and levels of these molecules may well be responsive to changes in cytoplasmic $\mathrm{pH}$. For example, calmodulin has a titratable histidyl residue at position 107 ; its activity may therefore be $\mathrm{pH}$ dependent. Tkachuk \& Men'Shikov (1981) showed that the amount of $\mathrm{Ca}^{2+}$ complexed to calmodulin varied by a factor of ten over a $\mathrm{pH}$ range between 6.5 and 7.5. If calmodulin is active in processing regulatory information during the dimorphic transition it may serve both as a 
proton and calcium sensor and thereby initiate its effects in response to alterations in internal $\mathrm{pH}$.

Modulations in the levels of cyclic nucleotides such as cAMP are known to be central to the regulation of cell metabolism and many morphogenetic systems. The $\mathrm{pH}$ activity profiles of adenylate cyclase and phosphodiesterase enzymes which make and destroy cAMP have been studied in a limited number of systems. In most cases it is clear that adenylate cyclase activity is often particularly sensitive to $\mathrm{pH}$ (see discussion of Busa \& Nuccitelli, 1984). Again it is possible to invoke mechanisms which incorporate changes in internal $\mathrm{pH}$ with modulations of those biochemical activities which are corporately responsible for the translation of an environmental signal into a switch from a budding to a mycelial growth habit. Whatever the details of the mechanism it is clear that changes in internal $\mathrm{pH}$ accompany structural dimorphism in $C$. albicans and may play a role in its control.

We thank Ian Booth, Frank Harold and Dale Sanders for helpful discussions and advice and the MRC for financial support (grant no. G8505330SB). We would also like to acknowledge the help of Mike Kinns, Mike Newman, Geoff Pye and Peter Troke with the NMR and Pfizer Central Research for the facilities for this.

\section{REFERENCES}

ANDERSon, J. M. \& Soll, D. R. (1984). Effects of zinc on stationary-phase phenotype and macromolecular synthesis accompanying outgrowth of Candida albicans. Infection and Immunity 46, 13-21.

Barton, J. K., DEN Hollander, J. A., Lee, T. M., Maclaughlin, A. \& Shulman, R. G. (1980). Measurement of the internal $\mathrm{pH}$ of yeast spores by ${ }^{31} \mathrm{P}$ nuclear magnetic resonance. Proceedings of the National Academy of Sciences of the United States of America 77, 2470-2473.

Booth, I. R., Mitchell, W. J. \& Hamilton, W. A. (1979). Quantitative analysis of proton linked transport systems: the lactose permease of Escherichia coli. Biochemical Journal 182, 687-696.

BORST-PAUWELS, G. W. F. H. (1981). Ion transport in yeast. Biochimica et biophysica acta 650, 88-127.

Buffo, J., Herman, M. A. \& Soll, D. R. (1984). A characterisation of $\mathrm{pH}$-regulated dimorphism in Candida albicans. Mycopathologia 85, 21-30.

Busa, W. B. \& Nuccitelli, R. (1984). Metabolic regulation via intracellular pH. American Journal of Physiology 246, R409-R438.

Cassone, A., Carpinelli, G., Angiolella, L., MadDaluno, G. \& PoDo, F. (1983). ${ }^{31} \mathrm{P}$ Nuclear magnetic resonance study of growth and dimorphic transition in Candida albicans. Journal of General Microbiology 129, 1569-1575.

Cassone, A., Sullivan, P. A. \& Shepherd, M. G. (1985). N-Acetyl-D-glucosamine-induced morphogenesis in Candida albicans. Microbiologica 8, 85-99.

Charbonneau, M. \& WebB, D. J. (1987). Weak bases partially activate Xenopus eggs and permit changes in membrane conductance whilst inhibiting cortical granule exocytosis. Journal of Cell Science 87, 205220.

Chattaway, F. W., Wheeler, P. R. \& O'Reilly, J. (1981). Involvement of adenosine $3^{\prime}: 5^{\prime}$-cyclic monophosphate in the germination of blastospores of Candida albicans. Journal of General Microbiology 123, 233-240.

Goffeau, A. \& Slayman, C. W. (1981). The protontranslocating ATPase of the fungal plasma membrane. Biochimica et biophysica acta 639, 197-223.
Gopal, P., Sullivan, P. A. \& Shepherd, M. G. (1982). Enzymes of $N$-acetyl-D-glucosamine metabolism during germ-tube formation in Candida albicans. Journal of General Microbiology 128, 2319-2326.

Gow, N. A. R. \& Gooday, G. W. (1982). Vacuolation, branch production and linear growth of germ tubes of Candida albicans. Journal of General Microbiology 128, 2195-2198.

Gow, N. A. R. \& Gooday, G. W. (1984). A model for the germ tube formation and mycelial growth form of Candida albicans. Sabouraudia 22, 137-143.

Gow, N. A. R., Henderson, G. \& Gooday, G. W. (1986). Cytological interrelationships between the cell cycle and duplication cycle of Candida albicans. Microbios 47, 97-105.

Gross, J. D., Bradbury, J., Kay, R. R. \& Peacey, M. J. (1983). Intracellular $\mathrm{pH}$ and the control of cell differentiation in Dictyostelium discoideum. Nature, London 303, 244-245.

Herman, M. A. \& Soll, D. R. (1984). A comparison of volume growth during bud and mycelium formation in Candida albicans : a single cell analysis. Journal of General Microbiology 130, 2219-2228.

Den Hollander, A., Ugurbil, K., BRown, T. R. \& Shulman, R. G. (1981). Phosphorus-31 nuclear magnetic resonance studies of the effect of oxygen upon glycolysis in yeast. Biochemistry 20, 5871-5880.

Hubbard, M. J., Bradley, M., Sullivan, P. A., SHEPHERD, M. G. \& ForRESTER, I. (1982). Evidence for the occurrence of calmodulin in the yeasts Candida albicans and Saccharomyces cerevisiae. FEBS Letters 137, 85-88.

Hubbard, M. J., Sullivan, P. A. \& Shepherd, M. G. (1985). The kinetics and divalent cation inhibition of the plasma membrane ATPase in the yeast Candida albicans. Journal of Biological Chemistry 260, 67826787.

Johnson, J. D., Epel, D. \& Paul, M. (1976). Intracellular $\mathrm{pH}$ and activation of sea urchin eggs after fertilisation. Nature, London 262, 661-664.

Krebs, H. A., Wiggins, D., Stubbs, M., Sols, A. \& BEDOYA, F. (1983). Studies on the mechanism of the antifungal action of benzoate. Biochemical Journal 214, 657-663. 
LeE, K. L., BuCKLey, H. R. \& CAmpbell, C. C. (1975). An amino acid liquid synthetic medium for the development of mycelial and yeast forms of Candida albicans. Sabouraudia 13, 148-153.

Maresca, B., Medoff, G., Schlessinger, D. \& KOBAYASHI, G. S. (1977). Regulation of dimorphism in the pathogenic fungus Histoplasma capsulatum. Nature, London 266, 447-448.

mattia, E., Carruba, G., Angiolella, L. \& CasSONE, A. (1982). Induction of germ tube formation by $\mathrm{N}$-acetyl-D-glucosamine in Candida albicans: uptake of inducer and germinative response. Journal of Bacteriology 152, 555-562.

Muthukumar, G. \& Nickerson, K. W. (1984). $\mathrm{Ca}(\mathrm{II})$-calmodulin regulation of fungal dimorphism in Ceratocystis ulmi. Journal of Bacteriology 159, 390392.

Muthukumar, G., Nickerson, A. W. \& Nickerson, K. W. (1987). Calmodulin levels in yeasts and filamentous fungi. FEMS Microbiology Letters 41, 253-255.

NiImi, M., Nimm, K., Tokunaga, J. \& Nakayama, H. (1980). Changes in cyclic nucleotide levels and dimorphic transition in Candida albicans. Journal of Bacteriology 142, 1010-1014.

ODDs, F. C. (1979). Candida and Candidosis. Leicester: Leicester University Press.

ODDs, F. C. (1985). Morphogenesis in Candida albicans. Critical Reviews in Microbiology 12, 45-93.
Prasad, R. \& Hofer, M. (1987). The electrochemical gradient of $\mathrm{H}^{+}$in Candida albicans and its relevance to the uptake of nutrients. Biochemistry International 14, 617-626.

San-Blas, G. \& San-Blas, F. (1984). Molecular aspects of fungal dimorphism. Critical Reviews in Microbiology 11, 101-127

Sanders, D. \& Slayman, C. L. (1982). Control of intracellular $\mathrm{pH}$. Predominant role of oxidative metabolism, not proton transport, in the eukaryotic microorganism Neurospora. Journal of General Physiology 80, 377-402.

Shepherd, M. G., Poulter, R. T. M. \& Sullivan, P. A. (1985). Candida albicans: biology, genetics and pathogenicity. Annual Review of Microbiology 39, 579-614.

Soll, D. R. (1985). The role of zinc in dimorphism. Current Topics in Medical Mycology 1, 258-285.

SolL, D. R. (1986). The regulation of cellular differentiation in the dimorphic yeast Candida albicans. Bioessays 5, 5-11.

TKaChuK, V. A. \& Men'Shikov, M. Y. (1981). Effect of $\mathrm{pH}$ on calcium binding properties of calmodulin and its interaction with the Ca-dependent form of cyclic nucleotide phosphodiesterase. Biokhimiya 138, 779-788.

Winkler, M. M. \& Grainger, J. L. (1978). Mechanism of action of $\mathrm{NH}_{4} \mathrm{Cl}$ and other weak bases in the activation of sea urchin eggs. Nature, London 273 , 536-538. 